\title{
Faktor-Faktor yang Mempengaruhi Kejadian Pedikulosis Kapitis pada Murid Kelas III, IV, V Dan VI SDN 019 Tebing Tinggi Okura Kecamatan Rumbai Pesisir Pekanbaru
}

\author{
Aprilia Zulinda $^{1}$, Yolazenia $^{2}$, Zahtamal $^{3}$
}

\begin{abstract}
Pediculosis capitis disease spread on to the whole world and found mostly in people with low in hygiene and socioeconomic. This Pediculosis capitis could be found in all age people especially in student age. The purpose of this research was to know description the factors that affect Pediculosis capitis case in $\mathrm{III}^{\mathrm{Id}}, \mathrm{IV}^{\text {th }}, \mathrm{V}^{\text {th }}$ and $\mathrm{VI}^{\text {th }}$ graders of SDN 019 Tebing Tinggi Okura in Rumbai Pesisir subdistrict of Pekanbaru. This cross sectional research had been done in March until August 2009 period. Sampel examination was done in macroscopicaly using serit comb to find the louse eggs and mature louses. From this study, 53 (39,3\%) of 135 sampel student were infected by Pediculus humanus capitis. Based on data analyses, there were known that sex, hair length, parents education, social and economical condition of the family, hair washing frequence, using tools related to hair together and comb cleaning custom variables had significant relation that affect Pediculosis capitis $(\mathrm{p}<0,05)$.
\end{abstract}

Keywords: pediculosis capitis, hair length, Tebing Tinggi Okura students.

Pedikulosis kapitis adalah suatu infestasi kulit dan rambut kepala yang disebabkan oleh kutu rambut kepala (Pediculus humanus capitis). Penyakit Pedikulosis kapitis dapat ditemukan di seluruh dunia pada semua usia terutama pada anak-anak dan dew ${ }^{1}$ asa muda. Insidensi tertinggi pada usia sekitar 3-12 tahun atau anak usia Sekolah Dasar (SD). Prevalensi di negara berkembang lebih tinggi dari negara maju, tetapi prevalensi pasti belum diketahui. ${ }^{1,2,3}$

Pedikulosis kapitis lebih sering timbul pada wanita dibandingkan pria. Penularan penyakit ini lebih sering melalui kontak kepala dengan kepala, namun dapat juga melalui benda-benda seperti sisir, topi, bantal dan asesoris rambut yang dipakai secara bergantian. Higienitas yang buruk juga dapat

\footnotetext{
1. Fakultas Kedokteran Universitas Riau

2. Penulis untuk korespondensi: Bagian Parasitologi Kedokteran Fakultas Kedokteran Universitas Riau, Alamat: Jl.DIponegoro No.1, Pekanbaru. Telp: 0761- 839264 ext 209, HP: 081365989440, Email: yolazenia@yahoo.com

3. Bagian ilmu Kesehatan Masyarakat-kedokteran Komunitas FK Unri
}

meningkatkan risiko terjadinya penyakit ini, misalnya jarang membersihkan rambut dan rambut panjang yang kotor pada wanita. ${ }^{3}$

Gejala-gejala yang ditimbulkan penderita Pedikulosis kapitis adalah perasaan gatal yang hebat oleh karena gigitan kutu rambut pada kulit kepala, sehingga menyebabkan si penderita berusaha untuk menggaruknya. Sepanjang siklus kehidupannya, nimfa dan kutu dewasa menyimpan kotorannya di kulit kepala yang akan menyebabkan timbulnya rasa gatal. Selain itu gatal juga ditimbulkan oleh liur dan ekskreta dari kutu yang dimasukkan ke dalam kulit waktu menghisap darah. Garukan yang dilakukan untuk menghilangkan gatal akan menyebabkan terjadinya erosi dan ekskoriasi sehingga memudahkan terjadinya infeksi sekunder. Perasaan gatal tersebut tentunya sangat mengganggu penderita. Pedikulosis kapitis pada anak SD bisa menyebabkan konsentrasi belajar anak terpecah, kurang tidur serta perasaan malu akibat telur-telur kutu yang terlihat pada rambut kepala si anak, sehingga mengganggu penampilannya. ${ }^{2,3,4}$ 
Berdasarkan hasil survey prevalensi infestasi Pediculus humanus capitis yang dilakukan pada murid kelas IV, V, dan VI SD Negeri 020 Tiga Batur Kecamatan Sungai Tarab Kabupaten Tanah Datar Sumatera Barat menunjukkan hasil sebesar 51,92\% murid terinfestasi. Dari survey tersebut juga ditemukan bahwa tingkat pendidikan, social ekonomi, panjang rambut, kebiasaan keramas, kebiasaan pemakaian bersama alat-alat yang berhubungan dengan rambut dan kebiasaan membersihkan sisir mempengaruhi kejadian pedikulosis kapitis. ${ }^{5}$

Penelitian mengenai Pedikulosis kapitis pada anak SD khususnya di Riau masih jarang dilakukan, serta mengingat di SD N 019 Tebing Tinggi Okura Kecamatan Rumbai Pesisir Pekanbaru terletak di daerah yang tergolong sanitasi lingkungannya yang kurang, pendidikan orang tua serta tingkat ekonomi penduduk tergolong rendah oleh karena itu peneliti tertarik untuk mengadakan penelitian mengenai Pedikulosis kapitis pada murid SD Negeri 019 Tebing Tinggi Okura Kecamatan Rumbai Pesisir Pekanbaru.

\section{METODE}

Jenis Penelitian yang digunakan adalah penelitian cross-sectional yang dilaksanakan pada bulan Maret sampai Agustus 2009 yang mengambil lokasi di SD N 019 Tebing Tinggi Okura Kecamatan Rumbai Pesisir Pekanbaru. Populasi dalam penelitian ini adalah semua murid kelas III, IV, V dan VI SD Negeri 019 tebing Tinggi Okura Kecamatan Rumbai Pesisir Pekanbaru. Sampel diambil dari semua populasi yang ada. Untuk menemukan telur kutu dilakukan pengamatan langsung kepala setiap responden, setelah itu digunakan sisir serit/sikat rapat untuk menemukan kutu rambut dewasa. Selain itu digunakan kuesioner untuk mengetahui faktor-faktor yang mempengaruhi kejadian Pedikulosis kapitis yaitu umur, jenis kelamin, panjang rambut, pendidikan orang tua, tingkat ekonomi keluarga murid, kebiasaan mencuci rambut sehari, kebiasaan pemakaian alat-alat rambut, dan kebiasaan membersihkan sisir.

Data yang terkumpul diolah dengan komputer menggunakan program SPSS. Analisis data dilakukan secara univariat dan bivariat. Data disajikan dalam bentuk narasi dan tabel distribusi frekuensi. Untuk melihat hubungan antara faktor risiko dengan kejadian Pedikulosis kapitis digunakan Uji chi square dengan derajat kepercayaan 95\% $(\mathrm{P}<0,05)$. Untuk melihat suatu kecenderungan terjadinya pengaruh faktor risiko antara kedua variabel yang diteliti digunakan Ratio Prevalens (RP).

\section{HASIL}

Penelitian ini dilakukan terhadap murid kelas III, IV, V, dan VI SDN 019 Tebing Tinggi Okura dengan jumlah 135 orang responden yang terdiri dari $74(54,8 \%)$ orang laki-laki dan $61(45,2 \%)$ orang perempuan. Dari 135 orang murid yang diperiksa kepalanya, didapatkan jumlah kasus penderita Pedikulosis kapitis sebanyak 53 orang murid $(39,3 \%)$ sedangkan yang tidak terinfestasi kutu rambut (Pediculus humanus capitis) sebanyak 82 orang murid $(60,7 \%)$ (Tabel 1).

Tabel 1. Distribusi frekuensi responden berdasarkan kejadian Pedikulosis kapitis.

\begin{tabular}{lcc}
\hline Pedikulosis kapitis & $\mathrm{N}$ & $\mathbf{\%}$ \\
Positif & 53 & 39,3 \\
Negatif & 82 & 60,7 \\
\hline Total & 135 & $\mathbf{1 0 0}$
\end{tabular}

Berdasarkan Tabel 2 dapat dilihat bahwa faktor jenis kelamin, panjang rambut, pendidikan orang tua, status ekonomi, kebiasaan keramas, kebiasaan pemakaian alat-alat rambut, kebiasaan membersihkan sisir mempunyai hubungan yang bermakna dengan kejadian infestasi P.humanus capitis. Selanjutnya bila dilihat dari nilai RP untuk semua variabel mempunyai nilai RP $>1$ pada rentang Confidence Interval (CI) $95 \%$ tidak mencakup angka 1,00 yang menunjukkan bahwa semua variabel merupakan faktor risiko. 
Tabel 2. Faktor-faktor yang mempengaruhi kejadian Pedikulosis kapitis pada responden

\begin{tabular}{|c|c|c|c|c|c|c|c|c|}
\hline \multirow{3}{*}{ No. } & \multirow{3}{*}{ Faktor risiko } & \multicolumn{4}{|c|}{ Infestasi P.humomus copitis } & \multirow[t]{3}{*}{ Total } & \multirow{3}{*}{$\begin{array}{c}\text { RP } \\
(\mathrm{CI} 95 \%)\end{array}$} & \multirow{3}{*}{$\begin{array}{c}\text { Nilai } \\
P\end{array}$} \\
\hline & & \multicolumn{2}{|c|}{ Positif } & \multicolumn{2}{|c|}{ Negatif } & & & \\
\hline & & $\mathrm{N}$ & $\%$ & $\mathrm{~N}$ & $\%$ & & & \\
\hline \multirow[t]{2}{*}{1.} & $\begin{array}{l}\text { Jenis kelamin } \\
\text { - Perempuan }\end{array}$ & 47 & 77,1 & 14 & 22,9 & 61 & 9,5 & 0,000 \\
\hline & - Laki-laki & 6 & 8,1 & 68 & 91,9 & 74 & $(4,3-20,7)$ & \\
\hline \multirow[t]{2}{*}{2.} & Panjang rambut & & & & & & & \\
\hline & $\begin{array}{l}\text { - Panjang } \\
\text { - Pendek }\end{array}$ & $\begin{array}{l}32 \\
21\end{array}$ & $\begin{array}{l}84,2 \\
21,6\end{array}$ & $\begin{array}{c}6 \\
76\end{array}$ & $\begin{array}{l}15,8 \\
78,4\end{array}$ & $\begin{array}{l}38 \\
97\end{array}$ & $\begin{array}{c}3,9 \\
(2,6-5.8)\end{array}$ & 0,000 \\
\hline \multirow[t]{3}{*}{3.} & Pendidikan ibu & & & & & & & \\
\hline & - Rendah & 48 & 51,1 & 46 & 48,9 & 94 & 4,2 & 0,000 \\
\hline & - Tinggi & 5 & 12,2 & 36 & 87,2 & 41 & $(1,8-9,7)$ & \\
\hline \multirow[t]{3}{*}{4.} & Status ekonomi & & & & & & & \\
\hline & - Rendah & 38 & 46,9 & 43 & 53,1 & 81 & 1,7 & 0,026 \\
\hline & - Tinggi & 15 & 27,8 & 39 & 72,2 & 54 & $(1,04-2,7)$ & \\
\hline \multirow[t]{3}{*}{5.} & Kebiasaan keramas & & & & & & & \\
\hline & - Baik & 21 & 24,1 & 66 & 75,9 & 87 & 2,8 & 0,000 \\
\hline & - Tidak baik & 32 & 66,7 & 16 & 33,3 & 48 & $(1,8-4,2)$ & \\
\hline \multirow[t]{3}{*}{6.} & $\begin{array}{l}\text { Kebiasaan pemakaian } \\
\text { alat-alat rambut }\end{array}$ & & & & & & & \\
\hline & - Baik & 22 & 24,4 & 68 & 75,6 & 90 & 2,8 & 0,000 \\
\hline & - Tidak Baik & 31 & 68,9 & 14 & 31,1 & 45 & $(1,8-4,2)$ & \\
\hline \multirow[t]{3}{*}{7.} & $\begin{array}{l}\text { Kebiasaan } \\
\text { membersihkan sisir }\end{array}$ & & & & & & & \\
\hline & - Baik & 16 & 20,0 & 64 & 80,0 & 80 & 3,364 & 0,000 \\
\hline & - Tidak baik & 37 & 67,3 & 18 & 32,7 & 55 & $(2,1-5,4)$ & \\
\hline
\end{tabular}

\section{PEMBAHASAN}

Berdasarkan hasil pemeriksaan rambut kepala secara makroskopis dengan menemukan telur kutu dan kutu rambut dewasa pada rambut responden, didapatkan frekuensi kejadian Pedikulosis kapitis pada murid kelas III, IV, V dan VI SDN 019 Tebing Tinggi Okura Kecamatan Rumbai Pesisir Pekanbaru sebesar 39,3\%, lebih banyak dari Malaysia menurut Sinniah frekuensi kejadian Pedikulosis kapitis pada anak Sekolah Dasar (SD) sebesar 10,7\%. ${ }^{6}$

Berdasarkan jenis kelamin didapatkan persentase kejadian Pedikulosis kapitis lebih banyak ditemukan pada perempuan $(77,1 \%)$ dibandingkan pada laki-laki $(8,1 \%)$ dan setelah dilakukan uji chi square antara jenis kelamin dengan kejadian Pedikulosis didapatkan adanya pengaruh yang signifikan. Hal ini sesuai dengan diutarakan Brown dan Sungkar bahwa frekuensi Pedikulosis kapitis lebih banyak menyerang pada perempuan daripada laki-laki. ${ }^{3,7} \mathrm{Hal}$ ini bisa disebabkan karena umumnya perempuan berambut lebih panjang daripada lakilaki, sehingga membutuhkan perawatan yang baik. Rambut yang kotor, lembab, jarang di sisir dan dikeramas merupakan tempat yang disukai untuk berkembangbiak kutu rambut kepala (Pediculus humanus capitis). ${ }^{8}$

Hal di atas didukung dari hasil penelitian dimana didapatkan perbedaan frekuensi kejadian Pedikulosis kapitis yang bermakna antara rambut panjang dengan rambut pendek dan rambut panjang merupakan faktor risiko terhadap kejadian Pedikulosis kapitis. Hal ini sesuai menurut Sungkar yang menyatakan kebersihan rambut yang kurang misalnya jarang membersihkan rambut dan rambut panjang yang kotor pada perempuan dapat meningkatkan risiko terjadinya kejadian Pedikulosis kapitis. ${ }^{3}$ Roza juga mendapatkan bahwa kejadian Pedikulosis kapitis sebesar $100 \%$ terjadi pada 
perempuan yang berambut panjang. ${ }^{4}$

Pendidikan orang tua murid didapatkan sebagian besar berpendidikan rendah dan didapatkan adanya pengaruh frekuensi Pedikulosis kapitis dengan tingkat pendidikan orang tua murid khususnya pendidikan ibu, hal ini sesuai yang didapatkan Roza bahwa kejadian Pedikulosis kapitis terjadi pada orang tua yang berpendidikan rendah khususnya Ibu (56,82\%). ${ }^{4}$ Pendidikan yang rendah pada ibu berhubungan dengan kejadian Pedikulosis kapitis disebabkan karena ibu lebih sering berinteraksi dengan anak-anaknya. Sedangkan pada pendidikan bapak belum tentu merupakan faktor risiko dengan kejadian Pedikulosis kapitis karena kurangnya kontak bapak dengan anak-anaknya. Pendidikan yang rendah berhubungan dengan perilaku kurang sehat misalnya kurang memperhatikan kebersihan kepala anak-anaknya sehingga kutu rambut kepala (Pediculus humanus capitis) suka berkembangbiak ditempat tersebut. Hal ini juga dibuktikan oleh Wijayanti (2008) yang menyatakan bahwa adanya hubungan perilaku sehat dengan angka kejadian Pedikulosis kapitis sebesar $100 \%$ dengan nilai $\mathrm{p}<0,05 .{ }^{9}$

Pada umumnya murid kelas III, IV, V dan VI SDN 019 Tebing Tinggi Okura Kecamatan Rumbai Pesisir Pekanbaru berasal dari status ekonomi miskin sebanyak 81 orang murid. Persentase kejadian Pedikulosis kapitis didapatkan lebih tinggi pada yang berasal dari status ekonomi miskin sebesar 46,9\% dan setelah dilakukan uji chi square antara status ekonomi keluarga dengan kejadian Pedikulosis kapitis didapatkan adanya pengaruh yang signifikan antara status ekonomi keluarga dengan kejadian Pedikulosis kapitis dan status ekonomi miskin merupakan faktor risiko terhadap kejadian Pedikulosis kapitis. Hal ini sesuai dengan yang diutarakan Graham R, Brown, Burns yang mengatakan bahwa kejadian Pedikulosis kapitis menjadi masalah pada masyarakat kelas bawah/ miskin. ${ }^{8}$ Hal ini juga dibuktikan pada penelitian roza (1997) didapatkan kejadian Pedikulosis kapitis sebesar $61,11 \%$ terjadi pada sosial ekonomi miskin. ${ }^{4}$ Namun pada saat sekarang kejadian Pedikulosis kapitis terjadi pula pada orang-orang jenjang sosial tinggi, berkembang didaerah perkotaan dan saat ini sudah menyebar luas ke semua sosial ekonomi. ${ }^{8}$

Berdasarkan kebiasaan hidup yang sehat, mencakup kebersihan rambut kepala ditemukan adanya pengaruh frekuensi kejadian Pedikulosis kapitis antara kebiasaan keramas yang teratur minimal 3 kali seminggu dengan yang tidak teratur dan kurang dari 3 kali seminggu, antara pemakaian sampo dan tidak menggunakan apa-apa, antara membersihkan sisir rambut yang teratur minimal 3 kali seminggu dengan yang tidak teratur dan didapatkan perbedaan yang bermakna setelah dilakukan uji statistik. Hal ini sesuai dengan penelitian Wijayanti (2008) didapatkan 100\% kejadian Pedikulosis kapitis dimana kerjadian ini terjadi pada anak-anak usia sekolah dimana usaha pencegahan, pemberantasan dan pengobatan masih jarang dilakukan oleh berbagai pihak sehingga mengakibatkan angka kejadian Pedikulosis kapitis masih tinggi. Kejadian ini bisa disebabkan tertular dan reinfeksi karena banyak masyarakat terutama anak-anak usia sekolah yang berprilaku kurang sehat. ${ }^{9}$

Berdasarkan cara penularan didapatkan bahwa terdapat hubungan antara kebiasaan pemakaian alatalat rambut seperti memakai sisir dengan kejadian pedikulosisi kapitis dan setelah dilakukan uji statistik didapatkan adanya pengaruh yang bermakna, didapatkan pengaruh kebiasaan membersihkan sisir kurang dari 3 kali seminggu sebesar 67,3\%. Hal ini mungkin disebabkan karena tidak pernahnya sisir tersebut dibersihkan sehingga kutu rambut kepala (Pediculus humanus capitis) dapat bergerak dengan cepat dan mudah berpindah dari satu hospes ke hospes lain. Kutu rambut kepala ini juga mudah ditularkan melalui kontak langsung atau dengan perantara barang-barang yang dipakai bersama-sama. Misalnya sisir, sikat rambut, topi dan lain-lainnya. ${ }^{6,10}$

\section{KESIMPULAN}

Berdasarkan hasil penelitian pada murid kelas III, IV, V dan VI SDN Tebing Tinggi Okura Kecamatan Rumbai Pesisir Pekanbaru ditemukan kejadian pedikulosis kapitis pada 53 orang murid $(39,3 \%)$ sedangkan yang tidak terinfestasi sebanyak 82 orang murid $(60,7 \%)$. Ditemukan adanya pengaruh yang bermakna antara jenis kelamin, panjang rambut, pendidikan orang tua, status ekonomi, kebiasaan keramas, kebiasaan pemakaian alat-alat rambut, kebiasaan membersihkan sisir dengan kejadian Pedikulosis kapitis. 


\section{UCAPAN TERIMA KASIH}

Penulis mengucapkan terima kasih yang sebesar-besarnya kepada kepala SDN 019 Tebing Tinggi Okura yang telah memfasilitasi guna terlaksananya penelitian ini. Tidak lupa kepada murid-murid SD yang telah bersedia menjadi sampel dalam penelitian ini.

\section{DAFTAR PUSTAKA}

1. Markel EK, John DT, Krotoski WA. Medical Parasitology. Eighth Edition.Toronto: WB saunders Company; 1999. p. 363-4.

2. Attok. Pediculosis capitis. Diakses dari : http:// www.emedicine.com. last updated November 25,2008.

3. Sungkar S. Beberapa aspek epidemiologi pedikulosis kapitis. Majalah kedokteran Indonesia 1994;44:640-4.

4. Oswari E. Penyakit dan Penaggulangannya. Jakarta: PT Gramedia Pustaka Utama; 1991.h.159-160.

5. Elvi R. Infestasi pediculus humanus capitis murid kelas IV, V dan VI SD No.20 Tiga Batur
Kecamatan Sungai Tarab Kabupaten tanah Datar dan Faktor yang mempengaruhinya (Skripsi).Padang: FK Unand;1997.

6. Sinniah B, Sinniah D, Rajeswari B. Epidemiology of Pediculus humanus capitis infestation in Malaysian school children. 1981. (Diakses tanggal 30 Agustus 2009). Dapat diakses pada: http://journal tropical medicine and hygiene.

7. Brown HW. Dasar Parasitologi Klinik. Edisi 3. Jakarta:Gramedia;1983.

8. Brown, Graham R, Burns T. Lecture notes on dermatology. Edisi 8. Surabaya:Erlangga;2005. p.42-54.

9. Wijayanti F. Hubungan antara perilaku sehat dengan angka kejadian Pedikulosis kapitis pada santriwati Pondok Pesantren Darul Ulum Jombang. 2008[diakses pada tanggal 30 agustus 2009]. Dapat diakses pada: http://gdhub-gdlgrey-2008-fitrianawi-1421.

10.Bariqina E, Ideawati Z. Perawatan dan Penataan Rambut. Yogyakarta : Adicita Karya Nusa; 2001.h. 1-45. 


\section{Petunjuk bagi Penulis Jurnal Ilmu Kedokteran (JIK) Journal of Medical Science}

1. Artikel yang ditulis untuk dimuat di Jurnal Ilmu Kedokteran (JIK) meliputi hasil penelitian, tinjauan pustaka dan laporan kasus di bidang kedokteran. Naskah diketik dengan huruf Times New Roman, ukuran 12 pts, dengan menggunakan spasi ganda (double), dicetak pada kertas A4 sepanjang maksimum 20 halaman, diserahkan dalam bentuk print-out sebanyak 3 eksemplar beserta soft copy-nya. Tulisan dibuat dalam format Microsoft Word. Pengiriman berkas dapat juga dilakukan melalui email sebagai attachment file yang dikirimkan ke alamat: jik bpk@ya-hoo.com

2. Nama penulis artikel dicantumkan tanpa gelar akademik dan ditempatkan di bawah judul artikel. Institusi asal penulis serta alamat coresponding author dapat dicantumkan pada catatan kaki.

3. Artikel ditulis dalam bahasa Indonesia atau Inggris dengan format esai, disertai judul pada masingmasing bagian artikel, kecuali bagian pendahuluan yang disajikan tanpa judul bagian. Judul artikel dicetak dengan huruf besar kecil tepi kiri, dengan huruf sebesar 14 poin. Peringkat judul bagian dinyatakan dengan huruf yang berbeda (semua judul bagian dan sub-bagian dicetak tebal atau tebal miring), dan tidak menggunakan angka/nomor pada judul bagian:

\section{PERINGKAT 1 (HURUF BESAR SEMUA, TEBAL, RATA TEPI KIRI)}

\section{Peringkat 2 (Huruf Besar kecil, Tebal, Rata Tepi Kiri)}

\section{Peringkat 3 ( Huruf Besar Kecil, Tebal-Miring, Rata Tepi Kiri)}

4. Sistematika artikel Tinjauan Pustaka (Jurnal Review) adalah: Judul; nama penulis (tanpa gelar akademik); abstrak (maksimum 100 kata); kata kunci; pendahuluan (tanpa judul) yang berisi latar belakang dan tujuan atau ruang lingkup tulisan; bahasan utama (dapat dibagi ke dalam beberapa sub-bagian); penutup atau kesimpulan; daftar rujukan (hanya memuat sumber-sumber yang dirujuk).

5. Sistematika artikel hasil penelitian adalah: judul; nama penulis (tanpa gelar akademik); abstrak (maksimum 150 kata) yang berisi tujuan, metode, hasil penelitian dan kesimpulan; kata kunci; pendahuluan (tanpa judul) yang berisi latar belakang, sedikit tinjauan pustaka, dan tujuan penelitian; metode; hasil; pembahasan; kesimpulan; ucapan terima kasih dan daftar rujukan(hanya memuat sumber-sumber yang dirujuk).

6. Sistematika laporan kasus adalah judul, abstrak, nama penulis (tanpa gelar akademik), laporan kasus, pembahasan, kesimpulan dan daftar rujukan

7. Sumber rujukan sedapat mungkin merupakan pustaka-pustaka terbitan 10 tahun terakhir. Rujukan yang diutamakan adalah sumber-sumber primer berupa laporan penelitian (termasuk skripsi, tesis, disertasi) atau artikel-artikel penelitian dalam jurnal dan/atau majalah ilmiah.

8. Perujukan dan pengutipan ditulis sesuai aturan Vancouver, diberi nomor urut sesuai dengan urutan pemunculan dalam keseluruhan teks, bukan menurut abjad. Cantumkanlah nama semua penulis bila tidak lebih dari 6 orang; bila lebih dari 6 orang penulis, tulis nama 6 penulis pertama diikuti et al. Jumlah rujukan sebaiknya dibatasi sampai 25 buah. Gunakan contoh yang sesuai dengan edisi ke 5 dari Uniform Requirements for Manuscript Submitted to Biomedical Journals yang disusun oleh International Commitee of Medical Journal Editors, 1977. Singkatan nama jurnal disesuaikan dengan Index Medicus. Hindarilah penggunaan abstrak sebagai rujukan. 
Untuk materi yang sudah dikirim untuk publikasi namun belum diterbitkan harus dirujuk dengan menyebutkannya sebagai pengamatan yang belum dipublikasi (Unpublished observation) seizin sumber. Makalah yang telah diterima namun belum terbit, dapat dirujuk dengan mencantum kata "in press".

9. Berikut adalah contoh cara menuliskan rujukan

\section{A Artikel standar}

Allen KJ, Soriano HE. Liver cell transplantation: the road to clinical application. J Lab Clin Med 2001;138:298-312.

Artikel yang lebih dari 6 penulis:

Block GD, Locker J, Bowen WC, Petersen BE, Katyal S, Strom SC, et al. Population expansion, clonal growth, and specific differentiation patterns in primary cultures of hepatocytes induced by HGF/SF, EGFand TGF alpha in a chemically defined (HGM) medium. J Cell

Biol1996;132:1133-1149.

Volume dalam suplemen

Iqbal K, Grundke-Iqbal I. Elevated levels of tau and ubiquitin in brain and cerebro-spinal fluid in Alzheimer's disease. Int Psychogeriatr 1997;9(Suppl. 1):289- 96.

\section{B Buku}

Penulis perseorangan

Murray CJL, Lopez A. The global burden of disease. Cambridge:Harvard University Press, 1996.

Editor sebagai penulis

Hilt W, Wolf DH, editors. Proteasomes: the world of regulatory proteolysis. George-town, Texas: Landes Bioscience;2000. p.1-391.

Bab dalam buku

Bulatao RA, Stevens PW. Estimates and projections of mortality by cause: a global overview, 1970-2015. In: Jamieson DT, Mosley WH, Eds. Evolving health sector priorities in developing countries. Washington: Population, Health and Nutrition Division, The World Bank, 1989.

Organisasi sebagai penulis

The World Bank. World Development Report 1993. Investing in health. New York: Oxford University Press, 1993.

\section{Disertasi/ Tesis/ Skripsi}

Kaplan SJ. Post-hospital home health care: the elderly/access and utilization (disertasi). St. louis (MO): Washington Univ.; 1995

\section{Artikel dari Internet}

Morse SS. Factors in the emergence of infectious diseases. Emerg Infect Dis (serial online) 1995 Jan-Mar (dikutip 5 Juni 1995);1(1):[24 screen]. Available from: URL: HYPERLINK http: // www.cdc.gov/incidod/eid.htm

10.Tata cara pengutipan, rujukan, tabel, dan gambar mengikuti ketentuan dalam buku PEGANGAN: Gaya Penulisan, Penyuntingan dan Penerbitan Karya Ilmiah Indonesia karya Mien A. Rifai (2005) atau mencontoh tata cara yang digunakan dalam artikel yang telah dimuat. Penulisan istilah Bahasa Indonesia sesuai dengan Pedoman Umum Ejaan Bahasa Indonesia yang Disempurnakan (Depdikbud, 1987). Artikel berbahasa Inggris menggunakan ragam baku. 
11. Semua naskah ditelaah secara anonim oleh mitra bestari (reviewers) yang ditunjuk oleh penyunting menurut bidang kepakarannya. Penulis diberikan kesempatan untuk memperbaiki naskah atas dasar rekomendasi/saran dari mitra bestari atau penyunting. Kepastian pemuatan atau penolakan naskah akan diberitahukan secara tertulis.

12.Pemeriksaan dan penyuntingan cetak-coba dikerjakan oleh penyunting dan/atau dengan melibatkan penulis. Artikel yang sudah dalam bentuk cetak-coba dapat dibatalkan pemuatannya oleh penyunting jika diketahui bermasalah.

13.Segala sesuatu menyangkut perijinan pengutipan atau penggunaan software komputer untuk pembuatan naskah atau ihwal lain yang terkait dengan HAKI yang dilakukan oleh penulis artikel, berikut konsekuensi hukum yang mungkin timbul karenanya, menjadi tanggung jawab penulis artikel tersebut.

14.Sebagai prasyarat bagi pemrosesan artikel, para penyumbang artikel wajib menjadi pelanggan minimal selama setahun. Penulis yang artikelnya dimuat wajib membayar kontribusi biaya cetak sebesar Rp. 250.000,00 (dua ratus lima puluh ribu rupiah) perjudul. Sebagai imbalannya, penulis menerima nomor bukti pemuatan sebanyak 2 (dua) eksemplar dan cetak lepas sebanyak 2 (dua) eksemplar. Artikel yang tidak dimuat tidak akan dikembalikan, kecuali atas permintaan penulis.

Makalah dapat dikirimkan kepada:

Penyunting/Editor Jurnal Ilmu Kedokteran

Jl. Diponegoro No. 1

Pekanbaru 28111

Indonesia 